\title{
DO VIETNAMESE STATE-DOMINATED LISTED FIRMS FACE FINANCE CONSTRAINTS?
}

\author{
Le Long Hau' ${ }^{1}$, De Ceuster Marc J.K. ${ }^{2}$, Plasmans Joseph ${ }^{3}$, Le Tan Nghiem ${ }^{4}$, Ha Minh Tri ${ }^{5, *}$ \\ ${ }^{1,4}$ Cantho University, Vietnam. \\ ${ }^{2}$ Universiteit Antwerpen, Prinsstraat 13, 2000 Antwerpen, Belgium - marc.deceuster@ua.ac.be \\ ${ }^{3}$ Universiteit Antwerpen, Prinsstraat 13, 2000 Antwerpen, Belgium - Joseph.plasmans@ua.ac.be \\ ${ }^{5}$ Ho Chi Minh City Open University, Vietnam. \\ *Email: tri.hm@ou.edu.vn
}

(Received: August 07, 2015; Revised: December 22, 2015; Accepted: May 17, 2016)

\begin{abstract}
Using accounting data of listed firms on the Vietnamese stock market this study documents that listed Vietnamese firms still face finance constraints, even after the introduction and rapid growth of the equity markets and the privatization wave that started since 1992. Contrary to most of the existing literature, especially large state-dominated firms were documented to be significantly more financially constrained.The cash flow sensitivity differences between the statedominated and private firms are economically large but statistically not significant.These findings are still consistent for both stock exchanges of Vietnam (HOSE and HNX).
\end{abstract}

Keywords: Vietnam; finance constraints; state-dominated.

\section{Introduction}

It is well known that information asymmetries make external finance more costly than internal finance (Fazzari et al., 1988). If financing becomes too costly, firms face difficulties to raise enough capital in order to realise their investment ambitions. These firms are said to be finance constrained. To overcome this fundamental problem of underinvestment, a well-functioning financial system is needed and must be established. Legislators all over the world have developed and implemented a mixture of two models of financial architecture: the Anglo-Saxon market based system and the GermanJapanese commercial banking driven system. Although the optimal design of the financial structure for developing countries is still debated (Ganesh Kumar et al., 2002), most of these countries have started to develop and foster their stock and loan markets as a channel of raising funds to finance firms' investments ${ }^{1}$. Following other developing countries, in 2000, Vietnam decided to provide an extra semi-direct financing channel through the stock market besides the existing direct financing through financial institutions. In addition, during the period 2006-2009 Vietnam has witnessed a fast development of the credit market through licensing more than 29 commercial banks (State Bank of Vietnam (SBV), 2011) ${ }^{2}$.

Despite the seemingly rapid growth of financing sources, it is often found that a reality check often is sobering. The growth of equity markets is potentially driven by speculative motives. Moreover, financing channels in developing countries often suffer from poor accounting practices, price manipulation, and so forth. As a consequence, 
the fact that these funding channels are quickly increasing in scale does not necessarily mean that they are sophisticated and/or driven by real economic growth (Shirai, 2004).

Vietnam probably is no exception to this concern. Moreover, despite the transition to a market based economy, significant stateownership of firms puts the Vietnamese economy forward as a particularly interesting case (see, for example, Nguyen and Meyer (2004)). Whereas it is often argued that due to soft budget constraints and a political pecking order, state-dominated firms are confronted to a lesser extent with credit constraints than private firms (for example, Poncet et al. (2010)), it is not clear whether this result carries over to Vietnam. In Vietnam, there historically exists a common belief that statedominated firms are problematic. Many statedominated firms suffered severely from a number of problems such as poor performance, bad corporate governance practices and disclosure of corruption by managers who are also governmental officials.

For example, it is publicly known that 11 State Civil Engineering Construction Corporations (CIENCOs) suffered substantial amounts of losses, where one of them lost up to VND 2 trillion (approximately USD 130 millions) (Nguyen and van Dijk, 2012). Likewise, subsidiaries of the Vietnam State Paper Corporation reported a loss of more than USD 2 million in 2004 (Nguyen, 2006). It is estimated that on average about $20-40$ per cent of the total investment from the state budget is lost and squandered by statedominated firms (Nguyen and van Dijk, 2012). Corporate governance of statedominated firms is another concern. The representatives of the state in the boards of state-dominated companies, mostly politicians, often insufficiently monitor the firms' activities since they tend to be more concerned with the chances of re-election or promotion (Nguyen and van Dijk, 2012). These managers, therefore, tend to maximise their own benefits rather than those of the state or the firm itself due to the agency problems and a lack of outside monitoring (Jensen and Meckling, 1976, Grossman and Hart, 1983).

These problems have created a lot of distrust concerning state-dominated firms and their operations. In order to remedy these problems and to attract capital investment from outside investors, state-dominated firms were privatised and listed on the stock exchanges to make them more transparent. This paper aims to answer the question whether a general distrust in firms, their managers and their owners puts finance constraints on them. We will show that listed Vietnamese state-dominated firms face finance constraints after the introduction and rapid growth of the equity markets and the privatization wave that started in the nineties. Especially large state-dominated firms are documented to be significantly more financially constrained.

The remainder of the paper is structured as follows. Section 2 gives an overview of the Vietnamese stock exchanges and their development, while section 3 reviews the existing literature. In section 4 , we present the methodology used. Section 5 describes the data and their descriptive statistics. Empirical results are discussed in section 6 . Finally, we conclude.

\section{Literature review}

Since the seminal study of Fazzari et al. (1988), the common approach for testing the presence of finance constraints is to split the sample of firms into a 'high-information cost' group and a 'low-information cost' group (Ganesh Kumar et al., 2002) using an a priori chosen information cost proxy. Firms that incur high information costs are expected to experience more finance constraints than those with low information costs. Fazzari et 
al. (1988) divide the sample into two groups depending on their payout rates. For both groups, they then regress the firms' investment on the firms' cash flow and a number of control variables. Under the assumption of a perfect capital market, one would not expect a statistically significant difference in the coefficient of the cash flow variable for the two groups. However, their findings show that the cash flow coefficient is larger for the group of firms with low payout rates, which indicates a higher level of finance constraint for this group.

Empirical studies differ with respect to the choice of the a priori proxy used to separate the two groups. Both firm characteristics, such as size, growth objective (R\&D objective) and ownership structure, as well as government policy oriented criteria were advanced. The choice of size as information cost proxy has spawned very mixed results ${ }^{3}$. A number of authors, for example, Devereux and Schiantarelli (1990), Kadapakkam et al. (1998) and Cleary (1999), found that large firms seem to face more finance constraints than small firms. Others, for example, Becchetti and Trovato (2002), however, documented the opposite result. To complete the spectrum, Audretsch and Elston (2002) found medium sized firms to be the most financially constrained. Research and Development (R\&D) activity is considered to be a discretionary investment. Therefore, firms which decide to invest in $R \& D$ are expected to be more financially constrained (Carreira and Silva, 2010). This hypothesis was widely supported for US firms (Himmelberg and Petersen, 1994), for Italian firms (Scellato, 2007) as well as for an Irish sample of firms (Bougheas et al., 2003). Ownership structure may affect the degree of financial constraints too. Domestic firms are found to be more financially constrained than foreign-owned firms (for example, Colombo and Stanca (2006) for Hungary, Hutchinson and Xavier (2006) for Slovenia and Blalock et al. (2008) for Indonesia). Poncet et al. (2010) argue that credit constraints are imposed on private Chinese firms but not on the Chinese state-dominated firms and foreign-owned firms.

\section{Methodology}

Notwithstanding some conflicting Hungarian evidence (Perotti and Vesnaver, 2004), empirical studies in transitional economies and developing countries typically find that state-dominated firms are less financially constrained than private firms (Poncet et al., 2010, Guariglia et al., 2011, Lizal and Svejnar, 2002). Soft budget constraints and a 'political pecking order' are often advanced as explanations of these findings. Soft budget constraints allow state-dominated firms to obtain funds irrespective of their indebtedness. Due to the so-called 'political pecking order' in the credit allocations of financial institutions, private firms are perceived as lower rank entities in terms of political status than state-dominated firms.

Vietnam shares many institutional features with other transitional and developing economies. Malesky and Taussig (2009) point, for example, at the importance of personal connections and political acquaintances in credit allocation. Moreover, the four state-dominated commercial banks (SOCBs), which account for at least three quarters of the total bank credit market, are expected to be generally more concerned with industry policy and the risk of non-payment by private borrowers than with profitability. An understandable reaction since there are strict punishments, including the possibility of jail time, to lending officers of SOCBs for their nonperforming loans to private firms (Le and Nguyen, 2009). Both facts suggest that state-dominated firms are better positioned to access bank loans than private firms and hence should be less financially constrained than their private counterparts. The general distrust that has 
been described in the introduction, however, leads us to conjecture the reverse: the ownership structure - state-dominated firm or private firm - is a viable candidate to be used as an a priori criterion to classify firms into a high (that is, state-dominated firms) and a low (that is, private firms) degree of the financially constrained group.

\subsection{Suggested model}

Fazzari et al. (1988) suggested modeling the behavior of investments as:

$\frac{I_{i, t}}{K_{i, t}}=f\left(\frac{X_{i, t}}{K_{i, t}}\right)+g\left(\frac{C F_{i, t}}{K_{i, t}}\right)+u_{i, t}$

where $I_{i, t}$ denotes the investments in plant and equipment for firm $i$ during period $t ; K_{i, t}$ symbolises the beginning-of-period capital stock for firm $i$ at period $t ; f$ is a function of $X_{i, t}$, where $X_{i, t}$ designates a vector of variables of theoretical investment determinants; $g$ is a function of the firm's internally generated cash flow $\left(C F_{i, t}\right)$ and $u_{i, t}$ is the error term.

Following Summers (1981) and Hayashi (1982), Fazzari et al. (1988) develop an empirical model to test for financing constraints, by introducing Tobin's $q$ (Tobin, 1969) in the equation to control for the market's evaluation of the firm's investment opportunities. Tobin's $q$ measures the ratio between the market value and the replacement value of the same asset. Fazzari et al. (1988) stated this empirically as

$\frac{I_{i, t}}{K_{i, t}}=\lambda_{i}+\alpha_{1} Q_{i, t}+\alpha_{2} \frac{C F_{i, t}}{K_{i, t}}+\varepsilon_{i, t}$

where $\lambda_{i}$ denotes a time invariant firmspecific constant, $Q_{i, t}$ approximates the value of marginal $q$ at the beginning of period $t$ and $\varepsilon_{i, t}$ is the error term. Finally, the other notations are the same as in the general form of investment equation (1).

Hubbard (1998) argued that the estimated coefficient, $\widehat{\alpha_{2}}$, in investment equation (2) should be zero under the absence of capitalmarket frictions as long as $Q_{i, t}$ controls adequately for a firm's investment; a significantly positive value of $\widehat{\alpha_{2}}$ suggests the presence of financing constraints.

Ganesh Kumar et al. (2001) and Carreira and Silva (2010), among many others, however, show that the measurement of Tobin's $q$ faces numerous practical difficulties, especially in the context of developing countries. In some cases, measuring Tobin's $q$ is even impossible due to the lack of precise data on the replacement value of assets. Given the high volatility of emerging stock markets such as the Vietnamese stock market, Tobin's $q$ may not reflect market fundamentals but instead be affected by "bubbles" or factors other than the present value of the expected future profits (Goergen and Renneboog, 2001, Bond et al., 2004). Besides, a large number of studies focusing on firm-level data often show the insignificance of $Q_{i}$. In cases where it turns out to be statistically significant, the estimates imply implausibly slow adjustment (Bond et al., 2004).

Taking all these issues into account, Athey and Laumas (1994), Harris et al. (1994) and Ganesh Kumar et al. (2001), (2002) suggest replacing Tobin's $q$ by the sales-accelerator model of investment developed by Abel and Blanchard (1987) in which they assume that past sales reflect the expectations of the future profitability of firm's investment. Following Ganesh Kumar et al. (2002), a possible empirical specification of the investment function for a panel of firms reads as

$$
\frac{I_{i, t}}{K_{i, t-1}}=\beta_{1} \frac{\Delta S_{i, t}}{K_{i, t-1}}+\beta_{2} \frac{C F_{i, t}}{K_{i, t-1}}+v_{i, t}
$$

and

$$
v_{i, t}=\lambda_{i}+\eta_{t}+\varepsilon_{i, t}
$$

where $\Delta S_{i, t}$ denotes changes in sales over period $t ; K_{i, t-1}$ represents the beginning-ofperiod capital stock for period $t$ symbolised by $K_{i, t}$ in equations (1) and (2); $v_{i, t}$ indicates a composite error term which consists of the time invariant firm-specific effect, $\lambda_{i}$, the common time effect, $\eta_{t}$, and the usual firmspecific and time-dependent error term, $\varepsilon_{i, t}$. 
Ganesh Kumar et al. (2002) argue that the internal cash flow $(C F)$ plays a key role in the empirical literature on finance constraints in advanced countries due to the fact that it is the most important source of financing firm's investment in those countries. However, in underdeveloped countries new external sources of funds $(\triangle E F)$ is the most important one since firms often start business with a far smaller capital stock than those in developed countries; hence, they hardly finance their inherent lumpy investments in plant and machinery using internal sources. An important fact supporting for this is that many underdeveloped countries perceive that lumpy investments vital to spur growth could not be financed through internal funds. Therefore, development finance institutions have been established to fill the gap in these countries. In such a situation, although external funds would be more costly than internal ones due to capital-market imperfections, the focus should be on external funds instead in the context of underdeveloped countries.

Given the above arguments, Ganesh Kumar et al. (2002) proposed replacing internal cash flow $(C F)$ by new external funds $(\triangle E F)$ in the investment specification (3) to test for the presence of finance constraints in the context of developing countries. Ganesh Kumar et al. (2002) also indicate that replacing of internal cash flow by external funds allows the decomposition of $\triangle E F$ into its constituents to identify the source(s) of external funds responsible for the finance constraints. Hence, the adjusted specification reads

$$
\frac{I_{i, t}}{K_{i, t-1}}=\gamma_{1} \frac{\Delta S_{i, t}}{K_{i, t-1}}+\gamma_{2} \frac{\Delta E F_{i, t}}{K_{i, t-1}}+v_{i, t}
$$

and,

$$
v_{\mathrm{i}, \mathrm{t}}=\lambda_{i}+\eta_{t}+\varepsilon_{i, t}
$$

where all variables are mentioned previously, except for $\triangle E F$ which denotes the new external sources of finance such as loans, bonds and equity finance.

Also, Sen et al. (1998) argue that external funding is the most important source of financing a firm's investment in underdeveloped countries. Hence, the focus on the investment constraints depending on a firm's access to external funds is highly relevant for Vietnam. Consequently, we use investment specification (4) to test for the presence of financial constraints for listed Vietnamese state-dominated firms.

The coefficient of $\Delta S\left(\widehat{\gamma_{1}}\right)$ is expected to be positive and significant according to the accelerator model. A significant positive and greater coefficient of $\Delta E F\left(\widehat{\gamma_{2}}\right)$ for the highinformation cost group of firms (that is, statedominated firms) than for the low-information cost group (that is, private firms) can be considered as sufficient evidence to support the hypothesis that the extent to which the firm's investment is sensitive to external funds varies across firm's types. In other words, it shows the evidence that listed firms are financially constrained.

\subsection{Methods}

Three estimation procedures can be applied for panel data analysis, that is, pooled Ordinary Least Squares (pooled OLS) estimation, random effect (RE) estimation or fixed effect (FE) estimation (Plasmans, 2006). However, the use of OLS models gives biased and inconsistent results if there is unobserved heterogeneity (unobserved individual-specific effects among firms). To avoid this bias, usually a FE estimator is used (Schaller, 1993, Perotti and Vesnaver, 2004). Moreover, since the data in this study cover almost all listed firms on both stock exchanges rather than a random sample drawn from a population of listed firms, the FE estimator is also a more appropriate estimator than the RE estimator (Dougherty, 2007). Consequently, we will use the FE estimator in our analysis.

\section{Data analyses}

\subsection{Data collected}

The study uses a panel of all firms that were listed on the Vietnamese stock 
exchanges at any time during 2006Q1 2009Q4. The panel consists of 417 firms ${ }^{4}$. Financials are not included in the sample because their balance sheet structure is completely different from that of industrials. Due to the lack of data availability in some periods for many firms, we use an unbalanced panel. All quarterly accounting data were obtained manually from the Hochiminh Stock Exchange (HOSE), the Hanoi Stock Exchange (HNX), and the websites of security firms and listed firms.

Following Guariglia et al. (2011), a firm is categorised as 'state-dominated firm' if the government holds more than 50 per cent of its total shares; otherwise it is assigned to the group of 'private firms'. This percentage of ownership is chosen as a cut-off point in time at the end of 2009Q4 due to the shortage of available data ${ }^{5}$. The choice of the end 2009Q4 is not likely to affect our study severely since it is not the objective of the paper to study the effect of firms' transitions from statedominated to private. Also, the use of a timeinvariant measure of state-ownership can minimise the measurement errors in this variable (Guariglia et al., 2011).

\subsection{Descriptive statistics}

Table 1 presents the descriptive statistics of all our variables. Summary statistics for the whole sample are shown in panel A. We notice a wide range of investment activities: some firms disinvest, others invest significantly vis-à-vis their capital stock. With respect to the financing variables, we notice that additional equity finance accounts for a much greater proportion than financing through long-term loans. This illustrates the importance of the new stock exchanges for the Vietnamese economy.

\section{Table 1. Descriptive statistics}

The table reports the descriptive statistics of all variables for the whole sample, the group of private firms and the group of state-dominated firms. In the table, INV denotes investment of the firm; $K_{(t-1)}$ is the previous-period capital stock of the firm; $\Delta S$ symbolizes the change in total sales; $\triangle E F$ denotes new external funds used to finance the firm's investment.

Panel A: Whole sample

$(\%)$

\begin{tabular}{llllll}
\hline Variable & Obs. & Mean & Std. & Min & Max \\
\hline$I N V / K_{(t-1)}$ & 1144 & 2.25 & 6.61 & -6.93 & 28.87 \\
$\Delta S / K_{(t-1)}$ & 1146 & 6.46 & 29.05 & -70.35 & 97.46 \\
$\Delta E F / K_{(t-1)}$ & 1144 & 5.72 & 5.59 & -6.16 & 24.86 \\
\hline
\end{tabular}

Panel B: Whole sample by firms' groups (private and state-dominated) (\%)

\begin{tabular}{lccccccccccc}
\hline & \multicolumn{4}{c}{ Private firms } & \multicolumn{5}{c}{ State-dominated firms } \\
\hline Variable & Obs. & Mean & Std. & Min & Max & Obs. & Mean & Std. & Min & Max \\
\hline$I N V / K_{(t-1)}$ & 689 & 2.86 & 6.72 & -6.93 & 28.87 & 455 & 1.33 & 6.32 & -6.85 & 28.35 \\
$\Delta S / K_{(t-1)}$ & 691 & 8.07 & 29.57 & -69.35 & 97.46 & 455 & 4.02 & 28.10 & -70.35 & 94.62 \\
$\Delta E F / K_{(t-1)}$ & 689 & 5.83 & 5.72 & -4.97 & 24.86 & 455 & 5.56 & 5.38 & -6.16 & 22.83
\end{tabular}


Panel C: For HOSE by firms' groups (private and state-dominated) (\%)

\begin{tabular}{lcccccccccc}
\hline & \multicolumn{4}{c}{ Private firms } & \multicolumn{5}{c}{ State-dominated firms } \\
\hline Variable & Obs. & Mean & Std. & Min & Max & Obs. & Mean & Std. & Min & Max \\
\hline$I N V / K_{(t-1)}$ & 426 & 3.59 & 6.60 & -6.93 & 28.83 & 137 & 1.34 & 6.10 & -6.82 & 27.84 \\
$\Delta S / K_{(t-1)}$ & 427 & 7.59 & 28.98 & -69.35 & 97.46 & 137 & 2.16 & 25.67 & -70.35 & 94.62 \\
$\Delta E F / K_{(t-1)}$ & 426 & 6.02 & 5.80 & -4.97 & 24.86 & 137 & 5.97 & 5.72 & -2.78 & 21.81 \\
\hline
\end{tabular}

Panel D: For HNX by firms' groups (private and state-dominated) (\%)

\begin{tabular}{lllllllllll}
\hline & \multicolumn{4}{c}{ Private firms } & \multicolumn{4}{c}{ State-dominated firms } \\
\hline Variable & Obs & Mean & Std. & Min & Max & Obs & Mean & Std. & Min & Max \\
\hline$I N V / K_{(t-1)}$ & 263 & 1.68 & 6.77 & -6.79 & 28.87 & 318 & 1.32 & 6.42 & -6.85 & 28.35 \\
$\Delta S / K_{(t-1)}$ & 264 & 8.85 & 30.54 & -57.69 & 96.32 & 318 & 4.82 & 29.08 & -65.98 & 92.52 \\
$\Delta E F / K_{(t-1)}$ & 263 & 5.52 & 5.60 & -4.81 & 22.10 & 318 & 5.38 & 5.23 & -6.16 & 22.83 \\
\hline
\end{tabular}

Panel B shows the descriptive statistics for state-dominated and private firms separately. The investment to the previousperiod capital stock ratio and the sales changes to the previous-period capital stock ratio of the private group are about two times higher than that of the state-dominated group. Descriptive statistics for HOSE and HNX are shown in Panel C and Panel D, respectively.

\section{Research findings}

Table 2 presents our estimation results. The specification (4) is estimated for the whole sample, and for each stock exchange (HOSE and HNX) individually to control for the heterogeneity between the two stock exchanges such as the listing criteria differences and development degree of each exchange $^{6}$. In case that the new external funds of a firm and its current sales level are highly correlated, endogeneity of regressors might occur (Ganesh Kumar et al., 2002). Although a priori we do not expect that financing decisions have a significant impact on firm's sales due to the long-term nature of these financing sources, the Durbin-Wu-Hausman
(DWH) tests (Davidson and MacKinnon, 1993) are employed to check the exogeneity of the financial variables and sales variable using one quarter lagged values of variables as instruments (Ganesh Kumar et al., 2002, Harris et al., 1994). As can be seen below, the tests cannot reject the exogeneity of new external finance $\left[\Delta E F / K_{(t-1)}\right]$ at the five per cent level in these specifications ${ }^{7}$.

Given these results, specifications (4) can be estimated in a consistent and efficient way by the OLS procedure (Ganesh Kumar et al., 2002) ${ }^{8}$. After that the coefficients of interested variables (that is, new external finance $\left.\left[\Delta E F / K_{(t-1)}\right]\right)$ are estimated for both groups of firms, a simple $t$-test is employed to compare between the two coefficients?

The estimation results of specification (4) are presented in Table. Some important points are worth noting. First, given the very low VIF statistics (that is, from 1.02 to 1.11) for all the regressions, it can be concluded that there is no evidence of multicollinearity. Second, the Wald statistics for a groupwise heteroskedasticity diagnostic test are highly statistically significant 
at the one per cent level, indicating that significant heteroskedasticity across firms is present. Hence, all specifications are estimated by taking into account this heteroskedasticity, that is, using cluster-robust standard errors, clustering by the panel variable (Baum, 2006) ${ }^{10}$.

All the estimated coefficients of $\left[\Delta S / K_{(t-1)}\right]$ are positive as predicted by the salesaccelerator model, except for the group of private firms in HNX. Nevertheless, only the coefficient for private firms listed on HOSE is statistically significant at 10 per cent. The estimated coefficients of $\left[\Delta E F / K_{(t-1)}\right]$ are positive and significant at the conventional levels indicating that listed firms face financial constraints in the sense that their investments are sensitive to the availability of new external financing. It turns out that this conclusion is mainly driven by the large (HOSE) listed firms. For smaller (HNX listed) private firms we find positive but not so statistically significant investment sensitivity. As we conjectured, the size of the sensitivity coefficient is greater for the state-dominated firms vis-à-vis private firms in all cases. A stronger discrepancy between the two groups is found for large (HOSE) listed firms. These results indicate that firms are financially constrained irrespective of their size, and that the extent to which firms are sensitive to the external finance seems to be greater for the group of state-dominated firms. However, a one-tailed $t$-test on the null hypothesis that state-dominated firms have a lower external funding sensitivity $\left(\mathrm{H}_{\mathrm{o}}: \Upsilon_{2 \text { (state-dominated firms) }} \leq\right.$ $\Upsilon_{2 \text { (private firms) }}$ ) can only be rejected for large (HOSE) listed firms at the 10 per cent level ${ }^{11}$. In other words, the evidence that statedominated firms are more financially constrained than private firms is only supported for large listed firms at the 90 per cent confidence level. Overall, these results show that distrusts to state-dominated firms still cannot completely outweigh their inherent favorable position (that is, soft budget constraints and 'political pecking order' theory). 


\section{Table 2. Estimation results of specification (4) for the whole sample, HOSE and HNX}

The table reports the estimated results of specification (4) for the whole sample and for each stock exchange. In the table, $I N V$ denotes investment of the firm; $K_{(t-1)}$ is the previous-period capital stock of the firm; $\Delta S$ symbolizes the change in total sales; $\Delta E F$ denotes total new external sources of funds used to finance the firm's investment. $t$-statistics are robust $t$-statistics after correcting for heteroskedasticity shown in parentheses. The $F$ - statistic is the result of the $F$-test on $R^{2}$. Diagnostic test statistics such as the variance inflation factor (VIF) and the Wald test statistic for groupwise heteroskedasticity are also reported. Finally, the notations ${ }^{*},{ }^{* *}$ and ${ }^{* * *}$ denote the significance levels of $10 \%, 5 \%$ and $1 \%$, respectively.

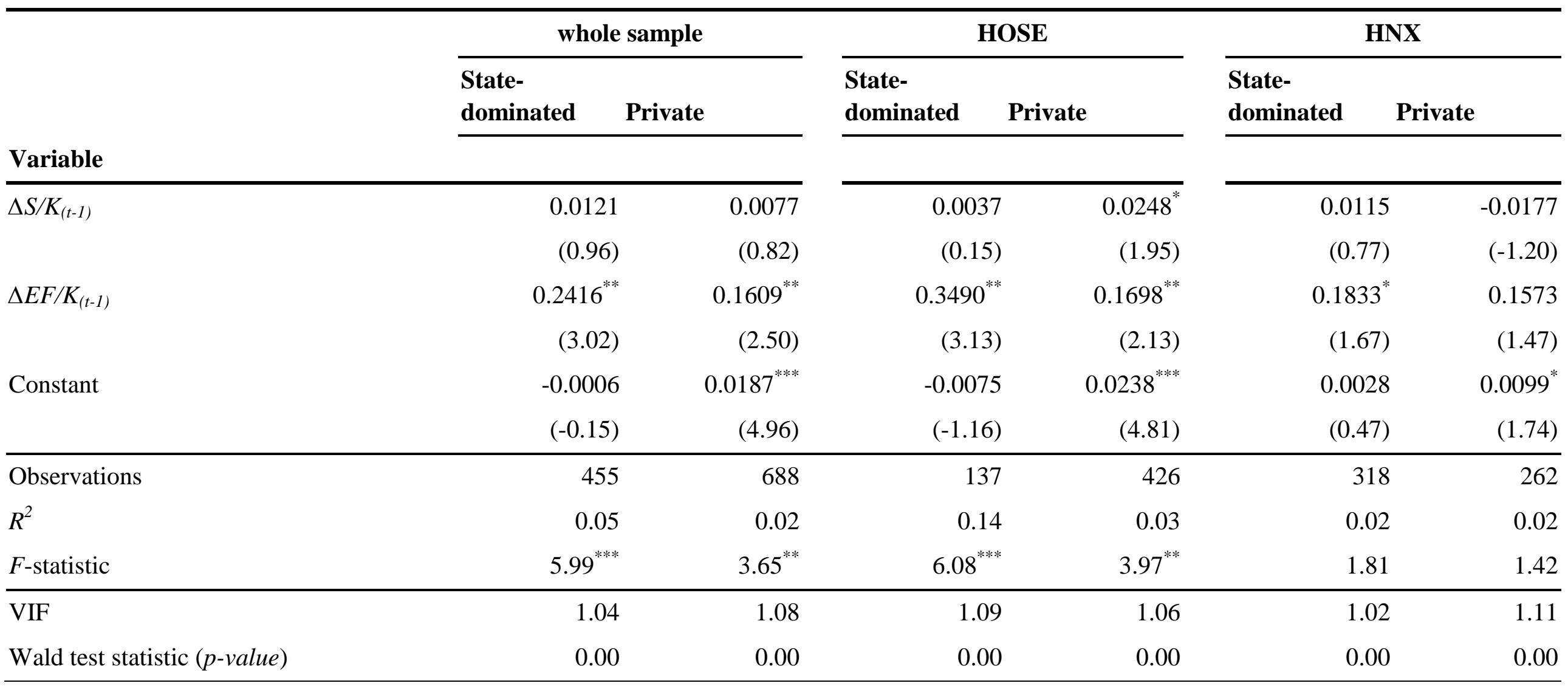




\section{Conclusion}

This study tests for the presence of finance constraints for Vietnamese listed firms. Vietnam is an interesting case since it is a developing economy in which previous research has casted doubt on the credibility of the governance structure of some statedominated entities. Hence, it allows us to test whether state-dominated corporates in general face less finance constraints than private firms, as suggested by (Poncet et al., 2010, Guariglia et al., 2011, Lizal and Svejnar, 2002).

Our results show that irrespective of their size and irrespective of the ownership structure (state-dominated versus private firms), Vietnamese firms' investments are sensitive to the availability of external funding. Although for smaller firms we do not find statistically significant different sensitivities between state-dominated and private firms, our evidence shows that large listed state-dominated firms are more financially constrained than private firms. These results contradict findings in the literature that claim that state-dominated firms face less finance constraints due to political pressure and soft budget constraints. Our results show that this issue is more complicated. We suggest that the credibility of corporate governance structures might play an important role in financing economic activity. If corporate governance is not perceived as trustworthy, markets stay reluctant to provide financing which results in higher cash flow sensitivity of investments.

Our findings suggest that the government should foster the privatization process and enforce credible corporate governance mechanisms. Large state-dominated firms do face higher financing constraints than private ones. As the privatization process proceeds, the political pressure will decrease and external funds will only be provided to investment worthy firms.

\section{Notes:}

1 For example, in 2009, the ratio of market capitalization to GDP reached 133 per cent for Malaysia, 49 per cent for Philippines, 100 per cent for China and 90 per cent for India, while this ratio is 105 per cent for US, 128 per cent for UK, 38 per cent and 66 per cent for Germany and Japan, respectively. Developing markets have also shown a relatively high growth over last decades, for instance the annual growth rate of the market capitalization over the period of 2000-2009 is on average 51 per cent for China and 36 per cent for India (World Bank, 2010).

2 The increasing in number of financial institutions makes the credit market more competitive. According to the World Bank, the ratio of the annual average domestic credit to GDP in the 2006-2009 period is relatively high, that is roughly 97 per cent p.a., (World Bank, 2011).

3 Ganesh Kumar et al. (2001) argue that size may not be a meaningful classification criterion in developing countries. In developed countries, larger firms with more fixed assets can offer a larger amount of collateral lenders. The key assumption is that the collateral is "marketable" that is it can be liquidated if required. However, this assumption may be problematic in the institutional context of developing countries. Particularly, the absence of well-developed bankruptcy laws and exit procedures may make the process of closing a firm and subsequently liquidating its assets become complicated and time-consuming on the part of creditors. Furthermore, the lack of secondary markets for various types of fixed assets may also result in the extremely high bankruptcy costs for firms.

4 Although the sample comprises of five industries, the composition of each industry in the total sample stays relatively stable over time using a $X^{2}$ test on contingency table.

5 Some main characteristics of both groups of firms using this classification criterion are worth mentioning here. The state-owned type firm group has an average percentage of state ownership of roughly $58 \%$, while in private type firm group the mean of state shares is approximately $14 \%, 11 \%$ and $17 \%$ for the whole sample, HOSE and HNX respectively. In addition, majority of state-owned type firms has the state ownership in the range from $50 \%$ to $70 \%$, while most of private type firms has the state shares of $0 \%-20 \%$. Since the difference in the average 
percentage of state ownership between the two firm group is fairly large, our conclusions might not seem to be severely biased.

6 This classification criteria up to a large extent can also help to control for firm size measured by the firm total assets. Using a simple $t$-test, we find that the average size of HOSE-listed firms is statistically significantly greater than that of HNX-listed firms.

7 The $p$-values of the DWH test statistics are reported in the bracket next to the variable for specification (4), $\left[\Delta E F / K_{(t-1)}\right](0.21)$.

8 One of the concerns raised by the panel econometric literature is cross-sectional or "spatial" dependence in many panel data sets in macroeconomics, international economics, regional science and finance (see, e.g., (Beck and Katz, 1995)). Failing to account for this dependence might result in inconsistently estimated standard errors (Driscoll and Kraay, 1998). In order to address this concern, we also estimate our specifications using the standard nonparametric time series covariance matrix estimator by Driscoll and Kraay (1998), which is robust to heteroscedasticity and very general forms of spatial and temporal dependence. Although the standard errors of coefficients are slightly changed in some cases, the results in general do not significantly change our conclusions.

9 It should be noted that this approach is appropriate only if the error terms and hence the estimated coefficients are assumed to be independently normally distributed. Indeed, we checked and found a very low covariance between the coefficients in the (estimated) regression equations.

10 We would like to show our gratefulness to C.F. Baum for suggesting the Stata command to take account of this issue.

11 We perform the following hypothesis test on the relevant coefficient: $\mathrm{H}_{\mathrm{o}}$ : coeff. of $\left[\Delta E F / K_{(t-1)}\right]_{(\text {state-owned firms) }} \leq$ coeff. of $\left[\Delta E F / K_{(t-1)}\right]_{(\text {private firms) }}$ versus $\mathrm{H}_{\mathrm{a}}$ : coeff. of $\left[\Delta E F / K_{(t-1)}\right]_{(\text {state-owned firms })}>$ coeff. of $\left[\Delta E F / K_{(t-1)}\right]_{(\text {(private firms) }}$ for the whole sample, HOSE and HNX. The $p$-values of the test statistic are 0.21, 0.09 and 0.43 , respectively.

\section{REFERENCES}

Abel, A. B. \& Blanchard, O. J. (1987). The present value of profits and cyclical movements in investment. National Bureau of Economic Research Cambridge, Mass., USA.

Athey, M. J. \& Laumas, P. S. (1994). Internal funds and corporate investment in India. Journal of Development Economics, 45, 287-303.

Audretsch, D. B. \& Elston, J. A. (2002). Does firm size matter? Evidence on the impact of liquidity constraints on firm investment behavior in Germany. International Journal of Industrial Organization, 20, 1-17.

Baum, C. F. (2006). An introduction to modern econometrics using Stata, Stata Corp.

Becchetti, L. \& Trovato, G. (2002). The determinants of growth for small and medium sized firms. The role of the availability of external finance. Small Business Economics, 19, 291-306.

Beck, N. \& Katz, J. N. (1995). What to do (and not to do) with time-series cross-section data. American political science review, 634-647.

Blalock, G., Gertler, P. J. \& Levine, D. I. (2008). Financial constraints on investment in an emerging market crisis. Journal of Monetary Economics, 55, 568-591.

Bond, S., Klemm, A., Newton-smith, R., Syed, M. \& Vlieghe, G. (2004). The roles of expected profitability, Tobin's Q and cash flow in econometric models of company investment. Bank of England Working Paper No. 222. 
Bougheas, S., Goerg, H. \& Strobl, E. (2003). Is R \& D financially constrained? Theory and evidence from Irish manufacturing. Review of Industrial Organization, 22, 159-174.

Carreira, C. \& Silva, F. (2010). No deep pockets: some stylized facts empirical results on firms' financial constraints. Journal of Economic Surveys, 24, 731-753.

Cleary, S. (1999). The relationship between firm investment and financial status. The Journal of Finance, 54, 673-692.

Colombo, E. \& Stanca, L. (2006). Investment decisions and the soft budget constraint. Economics of Transition, 14, 171-198.

Davidson, R. \& Mackinnon, J. G. (1993). Estimation and inference in econometrics. OUP Catalogue.

Devereux, M. \& Schiantarelli, F. (1990). Investment, financial factors, and cash flow: evidence from UK panel data. University of Chicago Press, 1990.

Dougherty, C. (2007). Introduction to econometrics, Oxford University Press, USA.

Driscoll, J. C. \& Kraay, A. C. (1998). Consistent covariance matrix estimation with spatially dependent panel data. Review of Economics and Statistics, 80, 549-560.

Egeln, J., Licht, G. \& Steil, F. (1997). Firm foundations and the role of financing constraints. Small Business Economics, 9, 137-150.

Fazzari, S., Hubbard, R. G. \& Petersen, B. C. (1988). Financing constraints and corporate investment. NBER working paper No. 2387.

Ganesh kumar, A., Sen, K. \& Vaidya, R. (2001). Outward orientation, investment and finance constraints: A study of indian firms. Journal of Development Studies, 37, 133-149.

Ganesh kumar, A., SEN, K. \& Vaidya, R. R. (2002). Does the source of financing matter? financial markets, financial intermediaries and investment in India. Journal of International Development, 14, 211-228.

Goergen, M. \& Renneboog, L. (2001). Investment policy, internal financing and ownership concentration in the UK. Journal of Corporate Finance, 7, 257-284.

Grossman, S. J. \& Hart, O. D. (1983). An analysis of the principal-agent problem. Econometrica: Journal of the Econometric Society, 7-45.

Guariglia, A., Liu, X. \& Song, L. (2011). Internal finance and growth: microeconometric evidence on Chinese firms. Journal of Development Economics, 96, 79-94.

Harris, J. R., Schiantarelli, F. \& Siregar, M. G. (1994). The effect of financial liberalization on the capital structure and investment decisions of Indonesian manufacturing establishments. The World Bank Economic Review, 8, 17-47.

Hayashi, F. (1982). Tobin's marginal q and average q: A neoclassical interpretation. Econometrica: Journal of the Econometric Society, 213-224.

Himmelberg, C. P. \& Petersen, B. C. (1994). R \& D and internal finance: A panel study of small firms in high-tech industries. The Review of Economics and Statistics, 76, 38-51.

Hubbard, R. G. (1998). Capital-market imperfections and investment. Journal of Economic Literature, 36, 193-225. 
Hutchinson, J. \& Xavier, A. (2006). Comparing the impact of credit constraints on the growth of SMEs in a transition country with an established market economy. Small Business Economics, 27, 169-179.

Jensen, M. C. \& Meckling, W. H. (1976). Theory of the firm: Managerial behavior, agency costs and ownership structure. Journal of Financial Economics, 3, 305-360.

Kadapakkam, P. R., Kumar, P. \& Riddick, L. A. (1998). The impact of cash flows and firm size on investment: the international evidence. Journal of Banking and Finance, 22, 293-320.

Lizal, L. \& Svejnar, J. (2002). Investment, credit rationing, and the soft budget constraint: Evidence from Czech panel data. Review of Economics and Statistics, 84, 353-370.

Malesky, E. J. \& Taussig, M. (2009). Where Is Credit Due? Legal Institutions, Connections, and the Efficiency of Bank Lending in Vietnam. Journal of Law, Economics, and Organization, 25, 535.

Nguyen, H. T. \& Meyer, K. E. (2004). Managing Partnerships with State-Owned Joint Venture Companies: Experiences from Vietnam. Business Strategy Review, 15, 39-50.

Nguyen, T. A. (2006). Fiscal risks from the perspective of state-owned enterprises in Vietnam. Paper under sponsorship of Ministry of Finance of Vietnam presented in APEC Finance Ministers' Meeting, Hanoi 2006.

Nguyen, T. T. \& Van Dijk, M. A. (2012). Corruption, growth, and governance: Private vs. stateowned firms in Vietnam. Journal of Banking and Finance, 36, 2935-2948.

Perotti, E. C. \& Vesnaver, L. (2004). Enterprise finance and investment in listed Hungarian firms. Journal of Comparative Economics, 32, 73-87.

Plasmans, J. 2006. Modern linear and nonlinear econometrics, Springer Verlag.

Poncet, S., Steingress, W. \& Vandenbussche, H. (2010). Financial constraints in China: firmlevel evidence. China Economic Review, 21, 411-422.

Scellato, G. (2007). Patents, firm size and financial constraints: an empirical analysis for a panel of Italian manufacturing firms. Cambridge Journal of Economics, 31, 55-76.

Schaller, H. (1993). Asymmetric information, liquidity constraints, and Canadian investment. Canadian Journal of Economics, 26, 552-574.

Sen, K., Vaidya, R. R. \& Sen, V. (1998). The process of financial liberalization in India, Oxford University Press, USA.

Shirai, S. (2004). Testing the three roles of equity markets in developing countries: the case of China. World Development, 32, 1467-1486.

State bank of vietnam (SBV) (2011). The System of Financial Institutions. http://www.sbv.gov.vn/.

Summers, L. H. (1981). Inflation, taxation, and corporate investment: A q-theory approach. NBER working paper No. 604.

Tobin, J. (1969). A general equilibrium approach to monetary theory. Journal of Money, Credit and Banking, 1, 15-29. 